\section{Alfred Blumberg \\ Carlos Zehnder \\ Andreas Huber}

Division of Nephrology and Central

Laboratory, Kantonsspital, Aarau,

Switzerland

\title{
Folic Acid Supplementation Rarely Improves Erythropoietin Response
}

Dear Sir,

Pronai et al. [1995] published an article in Nephron which claimed that folic acid supplementation improves erythropoietin (EPO) response. The authors studied 13 patients who were resistant to EPO given at a dosage of $75 \mathrm{U} / \mathrm{kg}$ (per week or per dose?). Eight patients responded with a fall in mean corpuscular volume (MCV) and a rise in hematocrit when they were given folic acid.

Based on this experience, we selected 14/ 71 patients on chronic hemodialysis who revealed an elevated MCV ( $>99 \mathrm{fl})$. Hemodialysis had been performed for 4-216 months; all patients were receiving $3 \times 4$ $5 \mathrm{~h} /$ week of hemodialysis with a high-flux, large surface area $\left(>1.8 \mathrm{~m}^{2}\right)$ dialyzer. All patients were on EPO treatment (duration 4 months to 10 years) given subcutaneously twice weekly in 12 (mean dose $100.5 \mathrm{U} / \mathrm{kg}$ / week) and 3 times weekly intravenously in 2 (mean dose $286 \mathrm{U} / \mathrm{kg} /$ week). Iron was intra- venously replaced regularly whenever serum ferritin fell below $100 \mu \mathrm{g} / \mathrm{l}$. The patients were studied before and after 1 month of a folic acid replacement of $5 \mathrm{mg} /$ day orally.

The results (mean $\pm \mathrm{SD}$ ) are shown in table 1.

Before folic acid supplementation, plasma folate was slightly lowered in 5 patients but only 1 of them had a low red cell folate level (which is a better indicator of tissue folate), Plasma vitamin $B_{12}$ concentrations were normal in all patients. Folate replacement increased plasma folate levels significantly. The EPO dose remained unchanged (98.0 s.c. and 286 i.v. U/kg/week). Neither mean MCV nor hemoglobin concentration changed significantly. Two patients of 13 had a moderate decrease of MCV (from 100 to 96 and 109 to $104 \mathrm{fl}$ ), but only 1 of the 2 patients showed a slight rise in hemoglobin from 136 to $141 \mathrm{~g} / \mathrm{l}$. The patient with low plasma and red cell folate levels showed a rise in plasma folate concentration from 4.3 to $21.5 \mathrm{nmol} / 1$ but her MCV (103 before, $101 \mathrm{fl}$ after) and hemoglobin (132 before, $130 \mathrm{~g} / \mathrm{gl}$ after) remained unchanged.

Although we agree with Pronai et al. that means of economizing EPO should be sought, our own results favor the conclusion that folic acid supplementation only rarely improves response to EPO in hemodialysis patients with an elevated MCV.

\section{Reference}

1 Pronai W, Riegel-Kell M, Silberauer K, Stockenhuber F: Folic acid supplementation improves erythropoietin response. Nephron 1995;71:395-400.

Table 1. Results

\begin{tabular}{|c|c|c|c|c|c|c|}
\hline \multicolumn{2}{|l|}{$\mathrm{MCV}, \mathrm{fl}$} & \multicolumn{2}{|c|}{ Hemoglobin, g/l } & \multicolumn{2}{|c|}{ Plasma folate, $\mu \mathrm{mol} / \mathrm{l}^{\mathrm{a}}$} & \multirow{2}{*}{$\frac{\text { Red cell folate, } \mathrm{ng} / \mathrm{ml}^{\mathrm{b}}}{\text { before }}$} \\
\hline before & after & before & after & before & after & \\
\hline $103.8 \pm 4.1$ & $102.4 \pm 3.5$ & $127.9 \pm 8.9$ & $128.9 \pm 6.4$ & $6.6 \pm 1.8$ & $26.9 \pm 18.9$ & $219.6 \pm 115.6$ \\
\hline
\end{tabular}

Normal range 5.7-38.3 $\mu \mathrm{mol} / 1$.

Normal range $90-300 \mathrm{ng} / \mathrm{ml}$.

\section{KARGER}

Fax + 41613061234 E-Mail karger@karger.ch www.karger.com

\section{() 1998 S. Karger AG, Basel \\ 0028-2766/98/0781-0115\$15.00/0}

This article is also accessible online at: http://BioMedNet.com/karger
Prof. Dr. med. Alfred Blumberg

Chefarzt Nephrologie

Departement Innere Medizin

Kantonsspital Aarau

CH-5001 Aarau (Switzerland) 